\title{
Front Matter: Volume 6963
}

, "Front Matter: Volume 6963," Proc. SPIE 6963, Unattended Ground, Sea, and Air Sensor Technologies and Applications X, 696301 (2 May 2008); doi: 10.1117/12.798098

SPIE Event: SPIE Defense and Security Symposium, 2008, Orlando, Florida, SPIE. United States 


\section{PROCEEDINGS OF SPIE}

\section{Unattended Ground, Sea, and Air Sensor Technologies and Applications $X$}

Edward M. Carapezza

Editor

17-20 March 2008

Orlando, Florida, USA

Sponsored and Published by

SPIE

Volume 6963 
The papers included in this volume were part of the technical conference cited on the cover and title page. Papers were selected and subject to review by the editors and conference program committee. Some conference presentations may not be available for publication. The papers published in these proceedings reflect the work and thoughts of the authors and are published herein as submitted. The publisher is not responsible for the validity of the information or for any outcomes resulting from reliance thereon.

Please use the following format to cite material from this book:

Author(s), "Title of Paper," in Unattended Ground, Sea, and Air Sensor Technologies and Applications $X$, edited by Edward M. Carapezza, Proceedings of SPIE Vol. 6963 (SPIE, Bellingham, WA, 2008) Article CID Number.

ISSN 0277-786X

ISBN 9780819471543

Published by

SPIE

P.O. Box 10, Bellingham, Washington $98227-0010$ USA

Telephone +1 3606763290 (Pacific Time) · Fax +1 3606471445

SPIE.org

Copyright (c) 2008, Society of Photo-Optical Instrumentation Engineers

Copying of material in this book for internal or personal use, or for the internal or personal use of specific clients, beyond the fair use provisions granted by the U.S. Copyright Law is authorized by SPIE subject to payment of copying fees. The Transactional Reporting Service base fee for this volume is $\$ 18.00$ per article (or portion thereof), which should be paid directly to the Copyright Clearance Center (CCC), 222 Rosewood Drive, Danvers, MA 01923. Payment may also be made electronically through CCC Online at copyright.com. Other copying for republication, resale, advertising or promotion, or any form of systematic or multiple reproduction of any material in this book is prohibited except with permission in writing from the publisher. The CCC fee code is 0277-786X/08/\$18.00.

Printed in the United States of America.

Publication of record for individual papers is online in the SPIE Digital Library.

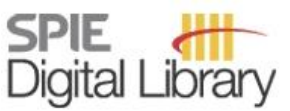

SPIEDigitalLibrary.org

Paper Numbering: Proceedings of SPIE follow an e-First publication model, with papers published first online and then in print and on CD-ROM. Papers are published as they are submitted and meet publication criteria. A unique, consistent, permanent citation identifier (CID) number is assigned to each article at the time of the first publication. Utilization of CIDs allows articles to be fully citable as soon they are published online, and connects the same identifier to all online, print, and electronic versions of the publication. SPIE uses a six-digit CID article numbering system in which:

- The first four digits correspond to the SPIE volume number.

- The last two digits indicate publication order within the volume using a Base 36 numbering system employing both numerals and letters. These two-number sets start with $00,01,02,03,04,05$, $06,07,08,09,0 \mathrm{~A}, 0 \mathrm{~B} \ldots \mathrm{OZ}$, followed by 10-1Z, 20-2Z, etc.

The CID number appears on each page of the manuscript. The complete citation is used on the first page, and an abbreviated version on subsequent pages. Numbers in the index correspond to the last two digits of the six-digit CID number. 


\section{Contents}

vii Conference Committee

xi Introduction

\section{KEYNOTE PRESENTATION}

696302 A vision of network-centric ISTAR and the resulting challenges (Keynote Paper) [6963-01]

G. Pearson, Defence Science and Technology Lab. (United Kingdom)

696303 Photon-counting passive 3D image sensing and processing for automatic target recognition (Keynote Paper) [6963-21]

S. Yeom, Daegu Univ. (South Korea); B. Javidi, Univ. of Connecticut (USA); E. Watson, Air Force Research Lab. (USA)

\section{SENSOR NETWORKING AND COMMUNICATIONS}

696305 Integration of unattended ground sensors into the tactical radio communications architecture [6963-03]

M. T. Cahill, H. M. Sasaki, Harris Corp. (USA)

696306 OmniSense unattended ground sensor system [6963-04]

J. McQuiddy, McQ Inc. (USA)

696307 SCORPION persistent surveillance system with universal gateway [6963-05]

M. Coster, J. Chambers, M. Winters, J. Belesi, Northrop Grumman Systems Corp. (USA)

696308 USMC UGS technology advancements [6963-06]

D. C. Hartup, M. E. Barr, P. M. Hirz, J. Kipp, T. A. Fishburn, E. S. Waller, B. A. Marks, L-3

Communications Nova Engineering (USA)

696309 Sustainable coastal sensor networks: technologies and challenges [6963-07]

E. M. Carapezza, Univ. of Connecticut, Avery Point (USA); J. Butman, Phase Coherence

(USA); I. Babb, A. Bucklin, Univ. of Connecticut, Avery Point (USA)

\section{TRANSIENTS DETECTION}

6963 OD Helmet-mounted acoustic array for hostile fire detection and localization in an urban environment [6963-11]

M. V. Scanlon, Army Research Lab. (USA)

$6963 \mathrm{OE}$ Acoustic detection and localization of small arms, influence of urban conditions [6963-12]

P. Naz, French-German Research Institute of Saint-Louis (France); Ch. Marty, DGA (France);

S. Hengy, P. Hamery, French-German Research Institute of Saint-Lovis (France) 
6963 OF Artillery/mortar type classification based on detected acoustic transients [6963-13] A. Morcos, D. Grasing, S. Desai, U.S. Army RDECOM (USA)

$69630 \mathrm{~A}$ Acoustic analysis of explosions in high noise environment [6963-14] H. Man, Stevens Institute of Technology (USA); S. Desai, U.S. Army RDECOM (USA)

$6963 \mathrm{OH}$ Three layers of battlefield gunfire protection: soldier, vehicle, and area protection sensors [6963-15]

R. L. Showen, R. B. Calhoun, W. C. Chu, J. Dunham, ShotSpotter, Inc. (USA)

\section{MODELING, SIMULATION, AND EXPERIMENTATION I}

$6963 \mathrm{Ol}$ Implementing statistical acoustic characterization of urban terrain into a decision support tool [6963-16]

H. H. Cudney, D. K. Wilson, S. A. Ketcham, U.S. Army Corps of Engineers (USA)

6963 OK Signal fading curves from computed urban acoustic wave fields [6963-19]

S. A. Ketcham, D. K. Wilson, M. W. Parker, H. H. Cudney, U.S. Army Engineer Research and Development Ctr. (USA)

$6963 \mathrm{OL}$ Sparse detector sensor model [6963-20]

A. L. Robinson, C. E. Halford, E. Perry, T. Wyatt, Univ. of Memphis (USA)

SIGNAL PROCESSING I

6963 OM Sparse detector sensor: profiling experiments for broad-scale classification [6963-22]

D. J. Russomanno, M. Yeasin, E. Jacobs, M. Smith, S. Sorower, Univ. of Memphis (USA)

6963 ON Qualitative performance of a local track repair algorithm for video tracking on small UAVs [6963-23]

S. DelMarco, BAE Systems (USA)

696300 Combining advanced imaging processing and low cost remote imaging capabilities [6963-24]

M. J. Rohrer, B. McQuiddy, McQ Inc. (USA)

6963 OP Efficient sensor network vehicle classification using peak harmonics of acoustic emissions [6963-25]

P. E. William, M. W. Hoffman, Univ. of Nebraska, Lincoln (USA)

6963 OQ Profiling sensor for ISR applications [6963-52]

R. B. Sartain, Army Research Lab. (USA)

SIGNAL PROCESSING ॥

6963 OR Multi-objects recognition for distributed intelligent sensor networks [6963-26]

H. He, S. Chen, Y. Cao, Stevens Institute of Technology (USA); S. Desai, M. E. Hohil, U.S. Army ARDEC (USA) 
6963 OT Improving temporal coherence to enhance gain and improve detection performance [6963-28]

R. A. Wagstaff, H. E. Rice, Univ. of Mississippi (USA)

6963 OU Coherence analysis of air and mechanically coupled ground vibrations [6963-29]

R. Burgett, Planning Systems Inc. (USA); J. M. Sabatier, Univ. of Mississippi (USA)

6963 OV Range limitation for seismic footstep detection [6963-30]

J. M. Sabatier, A. E. Ekimov, Univ. of Mississippi (USA)

UNATTENDED GROUND SENSORS (UGS)

6963 OW Helicopter detection using harmonics and seismic-acoustic coupling [6963-31]

T. R. Damarla, D. Ufford, Army Research Lab. (USA)

6963 0X Segregation of tracked and wheeled ground vehicle mobility mechanisms through in-situ adaptation of seismic features [6963-32]

C. G. Park, J. Fitzgerald, D. Power, Textron Systems Corp. (USA)

6963 OY iScout low cost UGS system: overview of enhancements and performance characterization [6963-34]

M. Winston, R. Klug, T. Plummer, R. Knobler, McQ Inc. (USA)

$69630 Z$ Target activated frame capture [6963-35]

G. M. Roberts, J. Fitzgerald, M. McCormack, R. Steadman, Textron Systems Corp. (USA)

ENABLING TECHNOLOGIES (SENSING, POWER, FUSION, ETC.)

696310 Stochastic analysis of unattended sensor battery life time [6963-36]

Q. Ge, Quigo Technologies (USA); R. Chandramouli, Stevens Institute of Technology (USA);

V. S. Swaminathan, S. V. Desai, U.S. Army RDECOM (USA)

696311 Miniaturization of electronics for a biomimetic acoustic direction finding system for use on multiple platforms [6963-37]

A. Hubbard, Boston Univ. (USA) and BioMimetic Systems, Inc. (USA); H. I. Cohen, Boston Univ. (USA); S. Deligeorges, BioMimetic Systems, Inc. (USA); D. Freedman, Boston Univ. (USA);

T. Gore, C. Karl, BioMimetic Systems, Inc. (USA); S. Kelsall, M. Nourzad, Y. Pu, Boston Univ. (USA); S. Xue, BioMimetic Systems, Inc. (USA)

696312 Warning equipment for UGS utilizing human body for data transmission and feeding [6963-38]

J. Cechak, Univ. of Defence (Czech Republic) 
696313 The development of a biomimetic acoustic direction finding system for use on multiple platforms [6963-39]

S. Deligeorges, BioMimetic Systems, Inc. (USA); D. Anderson, BioMimetic Systems, Inc. (USA) and Boston Univ. (USA); C. A. Browning, H. Cohen, D. Freedman, Boston Univ. (USA); T. Gore, BioMimetic Systems, Inc. (USA); C. Karl, Boston Univ. (USA) and BioMimetic Systems, Inc. (USA); S. Kelsall, Boston Univ. (USA); D. Mountain, BioMimetic Systems, Inc. (USA) and Boston Univ. (USA); M. Nourzad, Y. PU, M. Sandifer, Boston Univ. (USA); S. Xue, BioMimetic Systems, Inc. (USA); L. Ziph-Schatzberg, Boston Univ. (USA); A. Hubbard, Boston Univ. (USA) and BioMimetic Systems, Inc. (USA)

696314 A real-time biomimetic acoustic localizing system using time-shared architecture [6963-40] M. Nourzad Karl, C. Karl, A. Hubbard, Boston Univ. (USA)

696315 Advances in magnetometry [6963-41]

A. S. Edelstein, J. Burnette, G. A. Fischer, Army Research Lab. (USA); S. F. Cheng, Naval Research Lab. (USA); W. F. Egelhoff, Jr., P. W. T. Pong, National Institute of Standards and Technology (USA); E. R. Nowak, Univ. of Delaware (USA)

696316 Exploiting nonlinearity in an advanced dynamic magnetometer for UGS and MDA applications [6963-42]

A. R. Bulsara, V. In, A. Kho, P. Longhini, Space and Naval Warfare Systems Ctr. (USA);

S. Baglio, B. Ando, Univ. degli Studi di Catania (Italy)

696317 Progress with MEMS based UGS (IR/THz) [6963-43]

D. Grbovic, S. Rajic, N. V. Lavrik, P. G. Datskos, Univ. of Tennessee (USA)

\section{SESSION 10 MODELING, SIMULATION, AND EXPERIMENTATION II}

696318 Development, integration, testing, and evaluation of the U.S. Army Buckeye System to the NAVAIR Arrow UAV [6963-44]

R. L. Fischer, Science Applications International Corp. (USA); B. G. Kennedy, Neany, Inc. (USA); M. Jones, J. Walker, D. Muresan, G. Baxter, M. Flood, B. Follmer, Science Applications International Corp. (USA); X. Sun, W. Chen, Flight Landata, Inc. (USA); J. G. Ruby, U.S. Army Engineer Research and Development Ctr. (USA)

696319 Automated ship image acquisition [6963-45]

T. R. Hammond, Defence Research and Development Canada (Canada)

69631 A U.S. Army Research Laboratory (ARL) multimodal signatures database [6963-46]

K. Bennett, Army Research Lab. (USA)

Author Index 


\title{
Conference Committee
}

\author{
Symposium Chair
}

Larry B. Stotts, Defense Advanced Research Projects Agency (USA)

Symposium Cochair

Ray O. Johnson, Lockheed Martin Corporation (USA)

Program Track Chairs

Grant R. Gerhart, U.S. Army Tank-Automotive Research, Development and Engineering Center (USA)

Steve K. Rogers, Air Force Research Laboratory (USA)

Conference Chair

Edward M. Carapezza, University of Connecticut (USA) and Defense Advanced Research Projects Agency (USA)

Program Committee

Jacques Bédard, Defence R\&D Canada/Valcartier (Canada)

John G. Blitch, ARACAR: Alliance for Robot Assisted Crisis Assessment and Response (USA)

John C. Carrano, Luminex Corporation (USA)

Douglas S. Deadrick, BAE Systems (USA)

Christina J. Deckard, Space and Naval Warfare Systems Center, San Diego (USA)

John S. Eicke, Army Research Laboratory (USA)

Alan J. Gray, Defence Science and Technology Laboratory (United Kingdom)

Jeffrey R. Heberley, U.S. Army Armament Research, Development and Engineering Center (USA)

Todd M. Hintz, Space \& Naval Warfare Systems Command SPAWARSYSCEN (USA)

Myron E. Hohil, U.S. Army Research, Development and Engineering Command (USA)

Ivan Kadar, Interlink Systems Sciences, Inc. (USA)

Michael A. Kolodny, Army Research Laboratory (USA)

Frank Patton, Defense Advanced Research Projects Agency (USA)

Tien Pham, Army Research Laboratory (USA)

Nino Srour, Army Research Laboratory (USA)

Huub A. J. M. van Hoof, TNO (Netherlands)

Graeme van Voorthuijsen, TNO-FEL (Netherlands) 
Session Chairs

Keynote Presentation

Edward M. Carapezza, University of Connecticut (USA) and Defense Advanced Research Projects Agency (USA)

Todd M. Hintz, Space \& Naval Warfare Systems Command

SPAWARSYSCEN (USA)

Michael A. Kolodny, Army Research Laboratory (USA)

Sensor Networking and Communications

Tien Pham, Army Research Laboratory (USA)

Jeffrey R. Heberley, U.S. Army Armament Research, Development and Engineering Center (USA)

Myron E. Hohil, U.S. Army Research, Development and Engineering Command (USA)

Transients Detection

Myron E. Hohil, U.S. Army Research, Development and Engineering Command (USA)

Tien Pham, Army Research Laboratory (USA)

Modeling, Simulation, and Experimentation I

Graeme van Voorthuijsen, TNO-FEL (Netherlands)

Alan J. Gray, Defence Science and Technology Laboratory (United Kingdom)

Signal Processing I

Jeffrey R. Heberley, U.S. Army Armament Research, Development and Engineering Center (USA)

Michael A. Kolodny, Army Research Laboratory (USA)

Signal Processing II

Myron E. Hohil, U.S. Army Research, Development and Engineering Command (USA)

Tien Pham, Army Research Laboratory (USA)

Unattended Ground Sensors (UGS)

Michael A. Kolodny, Army Research Laboratory (USA)

Jacques Bédard, Defence R\&D Canada/Valcartier (Canada)

Enabling Technologies (Sensing, Power, Fusion, etc.)

Todd M. Hintz, Space \& Naval Warfare Systems Command SPAWARSYSCEN (USA)

Alan J. Gray, Defence Science and Technology Laboratory (United Kingdom) 
Acoustic, Magnetic, and Multi-modal Sensing

Graeme van Voorthuijsen, TNO-FEL (Netherlands)

Alan J. Gray, Defence Science and Technology Laboratory (United Kingdom)

Modeling, Simulation, and Experimentation II

Jeffrey R. Heberley, U.S. Army Armament Research, Development and Engineering Center (USA)

Todd M. Hintz, Space \& Naval Warfare Systems Command SPAWARSYSCEN (USA)

UGS Users

Michael A. Kolodny, Army Research Laboratory (USA) 
Downloaded From: https://www.spiedigitallibrary.org/conference-proceedings-of-spie on 25 Apr 2023

Terms of Use: https://www.spiedigitallibrary.org/terms-of-use 


\section{Introduction}

The interest in unattended sensor technologies and applications has dramatically increased over the past several years. Systems are being developed in support of military, homeland security, intelligence, law enforcement, physical security, and environmental monitoring applications around the world. Government agencies are making significant investments to develop improved unattended sensors and sensor networks. Recently, the United States and other countries have significantly increased the use of unattended ground, sea, and air sensors for homeland security applications, such as land border and coastal shore monitoring. This SPIE conference series is devoted to papers on recent technological advancements in unattended ground, sea, and air sensor technologies and applications.

The conference included five keynote/invited and 53 technical paper presentations organized into 13 sessions covering recent advances in Acoustic, Magnetic, and Multi-modal Sensing; Sensor Networking and Communications; Transients Detection; Modeling, Simulation, and Experimentation; Signal Processing; Enabling Technologies (Sensing, Power, Fusion, etc.); Integrated UGS Systems; and a UGS Users Panel.

Additionally, there were two joint keynote/invited sessions with Conference 6943 and one stand-alone keynote/invited session. The following five keynote/invited talks were given and we sincerely thank all of these speakers for very stimulating and relevant presentations:

1) A computational model of the human visual cortex by Dr. James Albus (National Institute of Standards and Technology)

2) MEMS and NEMS technologies for sensor applications by Dr. Panos Datskos (Oak Ridge National Laboratory and University of Tennessee)

3) Enhanced cyber security with CyLab Technologies by Dr. Pradeep Khosla (Carnegie Mellon University)

4) A vision of network-centric ISTAR and the resulting challenges by Mr. Gavin Pearson (Defence Science and Technology Laboratory, United Kingdom)

5) Design of trustworthy fielded sensor networks by Dr. Greg Pottie (University of California, Los Angeles)

6) Photon-counting passive $3 D$ image sensing and processing for automatic target recognition by Dr. Edward Watson (Air Force Research Laboratory)

We would also like to thank Mr. Michael Kolodny (Army Research Laboratory) for organizing and moderating a very interesting Unattended Sensor User Panel. We especially thank the following eight User Panel participants for making this panel so successful and an excellent wrap-up to this conference: Mr. Terrence Ryan (Marines-MARCORSYSCOM), Mr. Shawn McDonald (Navy-NAVSEA Dahlgren Divison), Mr. Bob McCaskey (Special Operations-SOCOM), Mr. Ken Grier and Mr. 
Charlie Gates (Defense Intelligence-DIA), Mr. Taylor Miller (Central CommandCENTCOM), Mr. John DellaGiustina (Army-TRADOC) and Mr. Robert O. Nelson (Department of Homeland Security-DHS).

Thanks to those who prepared and presented the technical papers for their contribution to a very successful meeting. The success of this conference is attributed to the participation of the commercial, university, and government research-and-development community as well as the organizing efforts of the diverse and talented program committee.

Thanks to our program committee members for their dedication, time, and assistance in conference planning and organizing and especially to those members who were able to participate as session chairs, including: Jacques Bédard (Defence R\&D Canada/Valcartier, Canada), Jeff Heberley (U.S. Army Armament Research, Development and Engineering Center), Todd Hintz (Naval Space and Warfare Center), Alan J. Gray (Defence Science and Technology Laboratory, United Kingdom), Myron E. Hohil (U.S. Army Research, Development and Engineering Command), Michael Kolodny (Army Research Laboratory), Tien Pham (Army Research Laboratory), and Graeme van Voorthuijsen (TNO-FEL, Netherlands).

Very special thanks to two program committee members who worked extra hard to help organize this challenging conference: Tien Pham and Todd Hintz. We could not have had so successful a technical conference without their excellent help and dedication.

Finally, an extra special thanks to all of the conference attendees this year for your interest and enthusiasm. The conference was well attended this year, with a lot of interest in all the sessions. We hope the interest in this technology continues to grow, and that this conference will expand with even greater technical content and significance in future years.

Edward M. Carapezza 